\title{
MIĘDZY PRECYZJĄ A NIEOSTROŚCIĄ - O PROBLEMATYCE PRZEKLADU NIEMIECKICH I POLSKICH TERMINÓW NIEOKREŚLONYCH
}

\author{
Karolina KESICKA, dr \\ Instytut Filologii Germańskiej, Wydział Neofilologii \\ Uniwersytet im. A. Mickiewicza \\ Al. Niepodległości 4, 61-874 Poznań \\ kesicka@amu.edu.pl
}

\begin{abstract}
Abstrakt: Celem artykułu jest przedstawienie problemów towarzyszących thumaczeniu terminów prawnych odnoszących się do pojęć nieostrych w prawie takich jak klauzule generalne i zwroty szacunkowe oraz ocena stopnia osiągnięcia ekwiwalencji semantycznej w przekładzie tychże terminów. W artykule wskazuje się na źródła i możliwe formy nieokreśloności semantycznej w terminologii specjalistycznej, ze szczególnym uwzględnieniem terminologii prawnej. Prezentację i omówienie przykładów klauzul generalnych i zwrotów szacunkowych poprzedza teoretyczna refleksja nad specyfiką pojęć nieostrych. Przedmiot analizy stanowią klauzule generalne i zwroty szacunkowe szczególnie relewantne dla polskiego i niemieckiego porządku prawnego. Badanie przeprowadzane jest przy użyciu modelu odwołującego się do zasad praktykowanych $\mathrm{w}$ modelach analizy prawno-porównawczej i obejmuje trzy etapy: analizę znaczenia danego pojęcia w porządku prawnym języka A, analizę prawno-porównawcza pojęcia pod kątem podobieństw/różnic między interpretacją pojęcia przez doktrynę w porządku prawnym języka A i B, a następnie analizę ekwiwalentu terminologicznego zaproponowanego w języku B.

Słowa kluczowe: pojęcia nieostre, klauzule generalne, zwroty szacunkowe, przekład prawniczy, komparatystyka prawnicza
\end{abstract}

\section{BETWEEN PRECISION AND VAGUENESS - THE PROBLEMS OF TRANSLATION OF GERMAN AND POLISH LEGAL VAGUE TERMS}

\begin{abstract}
The paper tries to outline the characteristics of vague legal terms and the problem of their translation. At the beginning of the article, the author points out some reasons for semantic indeterminacy in technical terminology, with particular focus on the language of the law. The discussion of examples is followed by the presentation of some theoretical issues related to vague legal terms. On that basis, the author presents examples of vague legal concepts and terms in the German and Polish civil law and analyses ways to handle translation problems with the assistance of legal interpretation and comparative law which were proposed in the translated legal texts and bilingual legal dictionaries. The applied analysis model based on the rules of comparative legal analysis will be made on the basis of the following steps: semantic analysis of the legal concepts defined in the source legal system, comparative legal analysis with a view to similarities/differences concerning the interpretation of the legal concepts in both legal systems and the analysis of terminological equivalence of translation into the target language.
\end{abstract}

Key words: vague legal concepts and terms, general clauses, legal translation, comparative law

Język prawa umiejscawia się w obszarze języka ogólnego, od którego zapożycza leksykę, dokonując przy tym często zmian semantycznych skutkujących jej terminologizacją. Terminologia prawna wykazuje m.in. następujące cechy gatunkowe terminu: 
Karolina Kęsicka, Między precyzją a nieostrościa - o problematyce przekładu...

sfera użycia (dziedzinowe zawężenie jej zakresu zastosowania),

(iii) identyfikowanie pojęć poprzez wskazywanie ich cech dystynktywnych (opozycja do innego terminu) (por. Gajda 1976, 15-28).

Dla tłumacza, który obok kompetencji językowej musi dysponować wiedzą fachową $\mathrm{z}$ danej dyscypliny, w dodatku nabywaną zwykle z pozycji zewnętrznego obserwatora, nieżyjącego w kulturze i porządku prawnym języka tłumaczenia, wynikają z przytoczonej w zawężeniu kompleksowości systemowej terminologii liczne trudności.

Jedną z nich jest sprzeczność dążności z jednej strony do precyzji pojęciowej, a $\mathrm{z}$ drugiej strony do zachowania otwartości semantycznej pojęć celem zachowania swobody ich interpretacji. W badaniach nad fenomenem nieokreśloności semantycznej lingwistyka języków specjalistycznych rozróżnia zasadniczo między niedookreśleniem / niezdeterminowaniem treści znaków językowych (dyfuzją semantyczną) oraz wieloznacznością treści. Oba zjawiska prowadzą do rozmycia się granic między znaczeniami. W germanistycznej refleksji dominuje odwoływanie się w tym zakresie do typologii dokonanej przez Manfreda Pinkala, który w obrębie nieokreśloności semantycznej wskazuje na takie jej postaci jak porowatość pojęć, nieostrość granic semantycznych, nieprecyzyjność, zaś w odniesieniu do wieloznaczności formy takie jak homonimia, polisemia, wieloznaczność o podłożu syntaktycznym, wieloznaczność referencyjna, wieloznaczność wypowiedzi eliptycznej czy dwuznaczność metaforyczna (por. Pinkal 1980, 11-23 oraz 1985, 61-92). Istotnym rozróżnieniem między wyrażeniami wieloznacznymi a nieostrymi stanowi fakt, że w odróżnieniu do wyrażeń wieloznacznych, których doprecyzowanie znaczenia wymaga kontekstu wypowiedzi i kontekstu językowego ich użycia, by spełniły one swoją funkcję komunikacyjną, niedoprecyzowanie określeń nieostrych nie musi skutkować zakłóceniem przebiegu komunikacji językowej.

Źródeł semantycznej nieokreśloności terminologii prawnej szukać należy przede wszystkim w specyfice pojęciowości prawnej, polegającej na tym, że rdzeń znaczenia pojęcia opisany w abstrakcyjnej normie jest w swej istocie bezkontekstowy i konkretyzuje się dopiero w drodze subsumcji i dokonywania wykładni normy prawnej. W wykładni normy treść pojęcia ulega kontekstowej konkretyzacji, której wynikiem jest powstanie definicji pojęcia.

W interpretacji pojęć prawnych pomocą nie tylko prawnikowi, lecz także tłumaczowi tekstów prawnych, służyć mogą definicje legalne, za pomocą których prawodawca może doprecyzować konkretny zwrot, likwidując lub ograniczając jego niedookreśloność. Warto przy tym zwrócić uwagę, że w odniesieniu do nazw semantycznie niedookreślonych ustawodawca likwiduje jej nieostrość poprzez wyznaczenie w definicji nieprzekraczalnych granic zakresu, może jednak dla zapewnienia elastyczności interpretacji chcieć zachować nieostrość zwrotu, jedynie w pewnym stopniu zwrot dookreślając. Jak zaznacza Zieliński „,W takim przypadku również zwroty definiujące bywają nieostre, tyle tylko, że mniej nieostre niż zwrot definiowany" (Zieliński 2012, 200). 


\section{Pojęcia nieostre}

Spośród cech gatunkowych terminu właśnie precyzja znaczeniowa okazuje się szczególnie problematyczna, gdyż prawodawca zmuszony jest do ciągłego balansowania między elastycznością tekstu prawnego a jego precyzją. W odróżnieniu od pojęć określonych, których semantykę precyzuje definicja legalna, niedoprecyzowanie semantyki pojęć nieostrych jest wręcz intencjonalne, gdyż pozwala ono na szerokie kontekstowo zastosowanie normy prawnej i osiągnięcie celu pragmatycznego normy. Pojęcia nieostre zapewniają prawodawcy konieczny luz decyzyjny, pozostawiając mu konkretyzację ich znaczenia według uznania. Nie jest to jednak równoznaczne z samowolą interpretacyjną prawodawcy, gdyż granicę swobody interpretacji wyznaczają granice pasa nieostrości danego pojęcia nieostrego.

$\mathrm{Z}$ perspektywy thumacza wynika $\mathrm{z}$ tego faktu trudność dokonania wyboru takiego ekwiwalentu terminologicznego, który pozwoli na zachowanie niedookreśloności pojęcia prawnego jako jego determinanty i tym samym nie doprowadzi do niezamierzonego przez ustawodawcę dokonkretyzowania znaczenia terminu. Problematyczną jest ponadto referencyjność pojęć nieostrych, które nie odnoszą się do konkretnych przedmiotów rzeczywistości pozajęzykowej, lecz często do nazw abstrakcyjnych kwalifikując je przy użyciu kryteriów szacowania. Kwalifikowaniu przez szacowanie podlegać może przykładowo zachowanie adresata normy czy intensywność danego zjawiska. Do grupy pojęć o semantycznej niedookreśloności zaliczają się pojęcia / zwroty takie jak: pojęcia nieokreślone (unbestimmte Rechtsbegriffe), pojęcia normatywne (normative Rechtsbegriffe), klauzule generalne (Generalklauseln) oraz klauzule uznaniowe (Ermessensklauseln) (por. Engisch 2010, 188-235). Jak zaznacza jednak sam Engisch terminologia nie jest jednorodna, stąd przyporządkowanie jej do wymienionej typologii pojęć często jest niejednoznaczne z uwagi na płynność granic między typami pojęć ( por. Engisch 2010, 192). Pod pojęciem nieokreślonym definiuje Engisch takie pojęcie, którego treść i zakres pozostają dalece niejednoznaczne wskutek jego wieloznaczności bądź nieostrości granic semantycznych (por. Engisch 2010, 193). W wielu przypadkach pojęcia te mają jednocześnie charakter normatywny, bowiem odnoszą się do zjawisk i obiektów, nie poddających się rzeczywistej percepcji, lecz których zrozumienie i percepcja są możliwe wyłącznie w relacji do systemu norm prawnych, który pozwala odczytać ich sens (por. Engisch 2010, 195-196). Sens pojęć normatywnych nie musi być jednakże zakotwiczony tylko w systemie prawnym, lecz również w ogólnym systemie wartości, z którego kulturowo się wywodzi. Normatywny oznacza zatem w tym sensie,wymagający oceny' (wertausfüllungsbedürftig) przez stosującego prawo w oparciu o własne uznanie bądź też przyjęte powszechnie wartości (por. Engisch 2010, 197). Takie ujęcie pojęć normatywnych zbliża je do prawno-filozoficznego rozumienia klauzul generalnych oraz zwrotów szacunkowych. Engisch nie posługuje się jednak terminologią zwrotu szacunkowego, lecz określa tę klasę pojęć jako klauzule uznaniowe, których podbudowę teoretyczną stanowi pojęcie uznania (Ermessen) (por. Engisch 2010, 201-208). Tym, co w ujęciu Engischa odróżnia pojęcia nieokreślone i normatywne od klauzul szacunkowych jest fakt, że w swej istocie nie są one uwarunkowane subiektywną oceną, ponieważ ich interpretacja i zastosowanie w danym wypadku pozostają ambiwalentne (por. Engisch 2010,212). Ostatnia z kategorii pojęć 
Karolina Kęsicka, Między precyzją a nieostrościa - o problematyce przekładu...

wyróżnianych przez Engischa to klauzule generalne, które charakteryzuje duży stopień ogólności, by uelastycznić stosowanie normy do możliwie wielu rzeczywistych zdarzeń. Jak podkreśla Engisch klauzule te zawierają odesłanie do norm pozaprawnych obiektywnie obowiązujących, a nie opartych o ocenę subiektywną, zaznaczając przy tym, iż ich rozgraniczenie $\mathrm{w}$ stosunku do pojęć nieokreślonych, normatywnych oraz klauzul uznaniowych jest w wielu wypadkach trudne do przeprowadzenia (por. Engisch 2010, 217). Z wyłonionej przez Engischa klasyfikacji pojęć wynika dla tłumacza terminologii prawnej wiele istotnych informacji odnośnie ontologicznego statusu pojęć nieokreślonych, jednocześnie $\mathrm{z}$ wskazanej przez samego autora trudności klasyfikacyjnej wielu pojęć zrodzić się może u tłumacza obawa o właściwe zakwalifikowanie i rozumienie danego pojęcia w toku analizy prawno porównawczej dokonywanej na potrzeby tłumaczenia.

Stąd też dla pewnego uporządkowania i niejakiego uproszczenia klasyfikacji pojęć pod kątem analizy przykładowych pojęć nieostrych posłużę się w tym miejscu klasyfikacją pojęć wg Müller-Tochtermanna, który szczególny akcent w swej analizie właściwości języka prawnego jako języka fachowego kładzie na leksykę. Rozróżnia on: pojęcia naturalne (natürliche Rechtsbegriffe), pojęcia nieokreślone (unbestimmte Rechtsbegriffe), pojęcia określone (bestimmte Rechtsbegriffe) oraz pojęcia wykształcone przez prawoznawstwo (rechtswissenschaftliche Rechtsbegriffe) (por. MüllerTochtermann 1959, 84-92). Pojęciami naturalnymi nazywa on pojęcia zaczerpnięte z języka ogólnego i na nowo zdefiniowane przez język prawa. W zależności od stopnia doprecyzowania znaczenia pojęcia naturalnego przez prawodawstwo (np. W drodze definicji legalnej) pojęcia te klasyfikowane są dalej jako określone bądź nieokreślone. Wreszcie ostatnią grupę tworzą pojęcia prawne o charakterze prymarnym, a więc nie stanowiące zapożyczeń z języka ogólnego, lecz wykształcone przez doktrynę prawa. Wydaje się, że klasyfikacja Müller-Tochtermanna pozwala tłumaczowi poprzez bardziej uogólniającą systematyzację pojęć na bardziej przejrzyste przyporządkowanie różnych kategorii pojęć nieokreślonych do klas semantycznych, niż ma to miejsce w przypadku odniesień do klasyfikacji wyodrębnionej przez Engischa. Pozwala ona bowiem na usytuowanie wszystkich grup pojęć nieostrych w obszarze tej samej klasy semantycznej pojęć nieokreślonych. Dla tłumacza nie będącego jednocześnie prawnikiem stanowi to istotne ułatwienie w jego pracy jako terminologa.

Mając na uwadze powyższą klasyfikację pojęć prawnych chciałabym w obrębie pojęć nieokreślonych poddać szczególnej analizie kategorie klauzul generalnych oraz zwrotów szacunkowych odsyłających do subiektywnej oceny stosującego prawo. Przedmiotem badania będzie zatem nieostrość semantyczna tych pojęć i wynikające $\mathrm{z}$ tego trudności dla tłumacza. Analiza oparta na wybranych przykładach pojęć i terminów zaczerpniętych $\mathrm{z}$ niemieckiego i polskiego prawa cywilnego przebiegać będzie trzyetapowo: 1) analiza znaczenia danego pojęcia w porządku prawnym języka wyjściowego; 2) analiza prawno-porównawcza pojęcia pod kątem podobieństw/różnic między interpretacją pojęcia przez doktrynę w porządku prawnym języka wyjściowego i docelowego, a następnie 3) analiza ekwiwalentu terminologicznego zaproponowanego w tłumaczeniu pod kątem ekwiwalencji pojęciowej z określeniem jej stopnia i oceną adekwatności zastosowanej strategii tłumaczeniowej. Przedstawione w analizie pojęcia i terminy stanowią przykłady szczególnie sygnifikantne dla poruszanej $\mathrm{w}$ artykule tematyki jako te, $\mathrm{z}$ którymi ze 


\section{Comparative Legilinguistics 17/2014}

względu na częstotliwość ich uzusu tłumacz stykać się będzie najczęściej. Na uwagę zasługuje przy tym ich różnoraki stopień ekwiwalencji w konfrontowanych porządkach prawnych, począwszy od pełnej ekwiwalencji pojęciowej, poprzez częściowe pokrywanie się semantyki pojęć, po całkowity brak ekwiwalencji. Jest to istotne dla końcowego etapu analizy, w którym przyjrzymy się, w jakim stopniu zakres ekwiwalencji znajduje odzwierciedlenie w decyzji tłumacza, przy czym w wielu wypadkach ekwiwalenty terminologiczne thumaczeniowe konfrontowane będą ekwiwalentami słownikowymi, a to z uwagi na możliwe rozbieżności terminologiczne.

Zaproponowany tu model komparatystycznej analizy przekładu terminologii fachowej nawiązuje w nieco zmodyfikowanej formie do modelu zaproponowanego przez Šarčević, w którym proces przekładu instytucji prawnych odbywa się analogicznie trzyfazowo, a więc analiza znaczenia danej instytucji w języku A, następnie analiza prawno-porównawcza i wreszcie rewerbalizacja pojęcia przy użyciu terminologii w języku B (por. Šarčević 1997, 148-150, 162-164) ${ }^{1}$. Taki trójpodział procesu analizy przekładu odzwierciedla, jak istotną wagę współczesna teoria przekładu przywiązuje do komparatystyki prawniczej jako instrumentu nieodzownego w pracy tłumacza języka prawnego. Jest oczywistym truizmem, że by móc przetłumaczyć, trzeba najpierw rozumieć. Lecz by móc zrozumieć, trzeba najpierw dane pojęcie zidentyfikować. W tym miejscu metodologia teorii przekładu spotyka się z metodologią komparatystyki prawniczej, w której niezależnie od preferowanego modelu procesu komparatystycznego zgodnie akcentuje się, że proces ten przebiega od identyfikacji $\mathrm{i}$ interpretacji porównywanych elementów / cech $\mathrm{w}$ danym porządku prawnym, przez porównanie zjawisk i ustalenie różnic i podobieństw między nimi, po krytyczną ocenę wyników, by móc ustalić istotne cechy wspólne i zdefiniować je $\mathrm{e}^{2}$.

\section{Klauzule generalne}

Klauzule generalne umożliwiają podmiotowi stosującemu prawo oparcie decyzji prawnej na kryteriach pozaprawnych, wskazanych w przepisie. Ich zasadnicza funkcja wyraża się w otwartości treści prawa na wartości i oceny pozaprawne ugruntowane w życiu społecznym i powszechnie akceptowane przez społeczeństwo. Umożliwia to rozszerzenie luzów decyzyjnych w procesie stosowania prawa i tym samym uelastycznia prawo, by można je było adaptować do różnorodności i zmienności zjawisk społecznych. Odesłanie do wartości i ocen pozaprawnych nie oznacza przy tym rzecz jasna oparcia decyzji o indywidualną ocenę podmiotu stosującego prawo wyrażającą jego akceptację stanu faktycznego podpadającego pod daną normę lub jej brak. Mają one bowiem charakter ocenny, ale nie wartościujący (zobacz szerzej np. w: T. Zieliński 1988, 29-30, M. Zieliński 2012, 181-184, R. Piszko 2001, 221).

\footnotetext{
${ }^{1}$ Podobnie jak Šarčević na trzyetapowy proces przekładu terminologii prawnej z koniecznością uwzględnienia $\mathrm{w}$ niej komparatystyki prawniczej jako instrumentu analizy wskazuje m.in. Bocquet 1994, 7-8.

${ }^{2}$ Por. przykładowe modele procesu komparatystycznego u L.-J. Constantinesco 1972, 137-232, H. Kötz i K. Zweigert, 1996, 31-47.
} 
Karolina Kęsicka, Między precyzją a nieostrościa - o problematyce przekładu...

Przykład 1.

Zasady współżycia społecznego (k.c. 2000, 4)

'Grundsätze des gesellschaftlichen Zusammenlebens' (poln. ZGB 2005, 4)

Przykładem powszechnie stosowanej klauzuli generalnej jest klauzula zasad współżycia społecznego. Klauzula ta odwołuje się do pozaprawnych norm społecznych oraz wartości moralnych i obyczajów, regulujących stosunki międzyludzkie. W zależności od kontekstu występowania spełnia ona m.in. funkcję 1) instrumentu pozwalającego zapobiec powstawaniu konsekwencji prawnych, które ze względu na szczególny kontekst sytuacyjny budziłyby powszechną dezaprobatę społeczną, czy też 2) elementu służącego doprecyzowaniu treści poszczególnych instytucji prawa cywilnego.

Klauzula zasad współżycia społecznego ukształtowana została w polskim prawie cywilnym w poprzedniej formacji ustrojowej. Wraz z transformacją ustrojową interpretacja klauzuli zaczęła podlegać stopniowej zmianie, stąd postuluje się nawet, by w doktrynie prawa cywilnego zastąpić ją konstrukcją dobrej wiary, zasad uczciwego obrotu, dobrych obyczajów, bądź zasad stuszności (zobacz szerzej np. w: Pajor 2009, 136). Ewoluowanie treści klauzuli zbliża jej rozumienie do zawartości semantycznej klauzul gute Sitten (pol. dobre obyczaje) oraz Treu und Glauben (pol. dobra wiara) obecnych w niemieckim prawie cywilnym.

Klauzula Treu und Glauben zobowiązuje mianowicie podobnie jak polska klauzula zasad współżycia społecznego do poszanowania interesów innych i uczciwego zachowania w obrocie prawnym. Porównajmy dla przykładu przepisy regulujące sposób wykonania zobowiązania przez dłużnika zawarte $\mathrm{w}$ polskim i niemieckim kodeksie cywilnym. Art. 354 k.c. stanowi w tym względzie, co następuje:

\section{Przykład 2.}

Art. $354 \S 1$. Dłużnik powinien wykonać zobowiązanie zgodnie z jego treścią i w sposób odpowiadający jego celowi społeczno-gospodarczemu oraz zasadom współżycia społecznego, a jeśli istnieją w tym zakresie ustalone zwyczaje także w sposób odpowiadający tym zwyczajom. (k.c. 2000, 63)

'Art. 354 [Treu und Glauben]. Der Schuldner hat seine Verpflichtung in Übereinstimmung mit ihrem Inhalt und in einer ihrer sozio-ökonomischen Zweckbestimmung und den Grundsätzen des gesellschaftlichen Zusammenlebens entsprechenden Art und Weise und, wenn in diesem Bereich bestimmte Gebräuche gelten, auch in einer diesen Gebräuchen entsprechenden Art und Weise zu erfüllen.' (poln. ZGB 2005, 65)

\section{Przykład 3.}

$\S 242$ BGB Leistung nach Treu und Glauben. Der Schuldner ist verpflichtet, die Leistung so zu bewirken, wie Treu und Glauben mit Rücksicht auf die Verkehrssitte es erfordern. (BGB 2002, 99) '§ 242. Dłużnik ma obowiązek świadczenie tak wykonać, jak tego wymagają uczciwość i zaufanie z uwzględnieniem zwyczajów życia potocznego. ${ }^{3}$ (KC, 1923)

3 Cytat pochodzi z polskiego przekładu BGB wydanego pod nazwą Kodeks Cywilny obowiazujacy na Ziemiach Zachodnich Rzeczypospolitej Polskiej (przekład urzędowy) przez Wydawnictwo Departamentu Sprawiedliwości Ministerstwa byłej dzielnicy pruskiej, T. X, 
Cytowany przepis z BGB zawiera także odesłanie do innej klauzuli, a mianowicie klauzuli Verkehrssitte, której interpretacja i kontekstowe użycie stanowić mogą analogię polskiej klauzuli ustalonych zwyczajów.

Poprzez zwrot Verkehrssitte rozumie się ustalone praktyki obowiązujące w obrocie prawnym w określonych kręgach. Analizując niemieckie thumaczenie wspomnianego wcześniej przepisu k.c. zauważyć należy, że oparte jest ono na dwóch różnych strategiach. W odniesieniu do klauzuli zasad współżycia społecznego tłumacz decyduje się $\mathrm{z}$ uwagi na ekwiwalencję funkcjonalną polskiej i niemieckiej klauzuli na zastosowanie analogii terminologicznej, wprowadzając śródtytuł do przepisu o treści „Treu und Glauben”. Strategii tej nie stosuje jednak konsekwentnie, rezygnując z ekwiwalentu funkcjonalnego w postaci terminu Verkehrssitte na rzecz thumaczenia dosłownego, mimo iż w komparatystyce prawniczej wskazuje się na analogię semantyczną terminów Verkehrssitte i ustalone zwyczaje (por. Heidenhain 2000, 58). Co zaś tyczy wariantów tłumaczenia niemieckiej klauzuli Verkehrssitte, to leksykony fachowe jak również autor tłumaczenia BGB sięgają po leksemy o wysokim stopniu uogólnienia (,zasady obowiązujące w określonych kręgach”), eksplikując jednak kontekst zastosowania owych zasad (,zwyczaj obrotu prawnego”).

Przykład 4.

Verkehrssitte (BGB 2002, 99)

'zasady obowiązujące w określonych kręgach، (Kilian 1996, 651)

'zwyczaj obrotu prawnego' (Kilian 1996, 595)

Porównując proponowane ekwiwalenty słownikowe $\mathrm{z}$ tłumaczeniowym stwierdzić należy, że zdecydowanie bardziej przybliżają one kontekst prawny użycia omawianego terminu, nawet mimo raczej parafrazującego charakteru, niż użycie w tłumaczeniu BGB leksemu potoczny, który sytuuje kontekst terminu Verkehrssitte w obszarze pozaprawnym. Mając jednak na uwadze czas powstania tłumaczenia BGB oczywistym jest, że niemożliwym było posłużenie się w nim analogią interpretacji między terminami Treu und Glauben oraz zasady wspótżycia społecznego, stąd zapewne z postrzegania niemieckiego terminu jako bezekwiwalentowy wynika dążność do dosłowności w tłumaczeniu.

\section{Przykład 5.}

nach billigem Ermessen (BGB 2002, 123)

'zgodnie ze słuszną oceną' (Kilian 1996, 134)

'według zasady słuszności' (Kozieja-Dachterska 2006, 181)

'(§ 315 f. BGB) uznanie wykonywane zgodne z zasadami słuszności‘ (Banaszak $2005,249)$

'uznanie/ocena według zasad słuszności‘ (Kilian 1996, 210)

Warszawa Poznań 1923. http://www.pwsz.legnica.edu.pl/ siejam/ustawy/bgb.doc, dalej KC (data dostepu 30.08.2013). 
Karolina Kęsicka, Między precyzją a nieostrościa - o problematyce przekładu...

Termin billiges Ermessen, który jako kolejny przykład chciałabym omówić, ma swoją podstawę semantyczną w pojęciu Billigkeit (engl. Equity), wywodzącym się z prawa rzymskiego, a następnie inkorporowanym przez Common Law w krajach anglosaskich, ale również w kontynentalnych europejskich systemach prawnych. Oznacza ono rozstrzyganie sporu w oparciu o zasady sumienia, uczciwości i sprawiedliwości. System equity pozostawia sądowi swobodę orzekania zgodnie $\mathrm{z}$ własnym sumieniem i poczuciem zdrowego rozsądku. Leksem billig został przez niemiecki język prawa przejęty i zawężony do rozumienia jako stuszny (niem. fair, angemessen) i w tym rozumieniu właściwie już nieużywanym w języku ogólnym. Termin Ermessen, obecny choćby w niemieckim prawie administracyjnym, wiązany jest $\mathrm{z}$ uwagi na swój kontekst użycia z polskim terminem uznanie administracyjne, tudzież z polską klauzulą zasad stuszności. Zastosowanie substytucji jest o tyle uzasadnione, że terminy billiges Ermessen oraz zasady słuszności wykazują semantyczną zbieżność np. w odniesieniu do ich rozumienia i kontekstowego uzusu w prawie zobowiązań. Przyjrzyjmy się treści $\S 315$ i nast. BGB regulujących oznaczenie świadczenia w stosunkach zobowiązaniowych, do którego odesłanie znajdujemy jako adnotację uzupełniającą w słowniku terminologicznym pod redakcją Banaszaka:

\section{Przykład 6.}

$\S 315$ Bestimmung der Leistung durch eine Partei. (1) Soll die Leistung durch einen der Vertragschließenden bestimmt werden, so ist im Zweifel anzunehmen, dass die Bestimmung nach billigem Ermessen zu treffen ist.

[...] (3) ${ }^{1}$ Soll die Bestimmung nach billigem Ermessen erfolgen, so ist die getroffene Bestimmung für den anderen Teil nur verbindlich, wenn sie der Billigkeit entspricht [...]. (BGB 2002, 123)

$\S 315$. Jeżeli świadczenie ma oznaczyć jedna ze stron zawierających umowę, należy w razie wątpliwości przyjąć, że oznaczenia należy dokonać wedle słusznej oceny.

[...] Jeżeli powinno się dokonać oznaczenia wedle słusznej oceny, dokonane oznaczenie wiąże drugą stronę tylko wtedy, gdy odpowiada słuszności. (KC 1923)

Zarówno w niemieckim jak i polskim prawie cywilnym swoboda umów i obyczajów pozwala stronom porozumieć się, że świadczenie po powstaniu zobowiązania zostanie oznaczone przez jedną ze stron bądź przez osobę trzecią. Co istotne, osoba oznaczająca świadczenie powinna to uczynić obiektywnie, z uwzględnieniem zasad słuszności. Oznaczenia świadczenia nie można dokonać z pokrzywdzeniem drugiej strony i z naruszeniem zasad, jakie obowiązują w obrocie prawnym, gdyż skutkuje to wówczas nieważnością zobowiązania. Świadczenie jest bowiem zachowaniem się dłużnika wobec wierzyciela zgodnym z treścią zobowiązania, mającym na celu zadośćuczynienie godnemu ochrony interesowi wierzyciela (por. art. $353^{1}$ oraz art. 354 k.c.).

Jak wynika zatem $\mathrm{z}$ analizy prawno-porównawczej wykładnia omawianych pojęć pozwala na kontekstowe zastosowanie analogii terminologicznej. Wśród ekwiwalentów proponowanych przez autorów słowników terminologicznych dominuje strategia ekspansji, mająca na celu eksplikację znaczenia terminu. Stąd uzupełnienia treści w postaci np. określenia „uznanie wykonywane”, nawiązujące zapewne do kontekstu użycia terminu Ermessensausübung, czy „według zasad słuszności / zgodnie z zasadami słuszności”, które z kolei budują konotację z klauzulą zasad słuszności 84 


\section{Comparative Legilinguistics 17/2014}

w polskim prawie. Wydaje się, że strategia ekspansji sprawdza się zdecydowanie lepiej niż propozycja ekwiwalentu tłumaczeniowego „wedle słusznej oceny”, która ciąży ku zbytniej dosłowności i nie oddaje aspektu uznaniowości decyzji uprawnionego do niej organu.

\section{Zwroty szacunkowe}

Semantyczna nieokreśloność cechuje obok klauzul generalnych także zwroty szacunkowe. Wyrażają one przykładowo kryterium oceny sytuacji, oceny zachowania adresata normy lub oszacowanie stopnia intensywności danego zjawiska, określonego normą prawną. Terminy te zawierają każdorazowo przedstawienie stanu faktycznego w oparciu o przesłanki, które pozwalają stwierdzić zaistnienie danego stanu faktycznego oraz element ocenny danego stanu faktycznego (np. istotny, stosowny itp.). Zwroty szacunkowe nie odwołują się przy tym, jak klauzule generalne, do aprobowanych społecznie systemów wartości, lecz pozwalają ocenić sytuację wyłącznie pod kątem intensywności bądź stosowności (zobacz szerzej w: M. Zieliński 2012, 181 $185)$.

Z punktu widzenia tłumacza jako problematyczne uznać należy występowanie w zwrotach szacunkowych przymiotników, które służyć mają ocenie intensywności bądź odpowiedniości. Oto kilka przykładów z niemieckiego i polskiego kodeksu cywilnego:

\section{Przykład 7.}

$\S 530$ Widerruf der Schenkung. (1) Eine Schenkung kann widerrufen werden, wenn sich der Beschenkte durch eine schwere Verfehlung gegen den Schenker oder einen nahen Angehörigen des Schenkers groben Undanks schuldig macht. (BGB 2002, 166)

'§ 530 Darowiznę można odwołać, gdy obdarowany wskutek ciężkiego uchybienia względem darującego lub bliskiego członka rodziny tegoż, staje się winnym ciężkiej niewdzięczności.' (KC, 1923)

W przykładzie 7 ustawodawca niemiecki posługuje się przymiotnikiem grob w celu dokonania oceny modus operandi osoby obdarowanej, stanowiącego możliwą podstawę odwołania darowizny, a oznaczającego poważne naruszenie normy zachowania. Także w kontekście prawa karnego użycie przymiotnika grob wiąże się z zasadniczym naruszeniem normy prawnej. Niedookreśloność leksemu wyraża się w tym wypadku w tym, że nie sposób określić granicy między akceptowalnością a nieakceptowalnością danego zachowania. Poprzez pojęcie grober Undank BGB rozumie sytuację, w której osoba obdarowana dopuszcza się ciężkiego uchybienia względem darczyńcy, które jako takie właśnie uznane zostaje przez udzielającego darowiznę. Zachowanie obdarowanego uznaje się za rażąco niewdzięczne wtedy, gdy naznaczone jest złą wolą i zamiarem wyrządzenia darczyńcy szkody lub krzywdy. Podobną wykładnię ma zwrot rażąca niewdzięczność użyty w art. $898 \S 1$ k.c., w którym mowa jest o okolicznościach stanowiących podstawę odwołania darowizny:

\section{Przykład 8.}


Karolina Kęsicka, Między precyzją a nieostrościa - o problematyce przekładu...

Art. 898. [Odwołanie darowizny wykonanej] § 1. Darczyńca może odwołać darowiznę nawet już wykonaną, jeżeli obdarowany dopuścił się względem niego rażącej niewdzięczności. (k.c. 2000, 166)

'Art. 898 [grober Undank]. § 1. Der Schenker kann eine schon vollzogene Schenkung widerrufen, wenn sich der Beschenkte ihm gegenüber groben Undanks schuldig gemacht hat.' (poln. ZGB 2005, 190)

Stosując zatem substytucję terminologiczną tłumacz nie popełnia błędu czy też nadużycia, gdyż w omawianym przykładzie mamy do czynienia $\mathrm{z}$ całkowitą ekwiwalencją pojęciową. W historycznym już dziś przekładzie BGB z roku 1923 posłużono się jednak w tym miejscu ciążącym ku pewnej dosłowności i dość niezręcznym stylistycznie zwrotem ciężka niewdzięczność, w którym użyta przydawka odwołuje się semantycznie zapewne do zwrotu ciężkie uchybienie (tu: normie zachowania), szacując wagę okazywanej przez obdarowanego niewdzięczności.

Dla porównania, by zachować semantyczną nieostrość zwrotu grober Undank w tłumaczeniu, współczesne słowniki terminologiczne proponują zastosowanie substytucji w postaci leksemu rażacy:

\section{Przykład 9.}

grober Undank (BGB 2002, 166)

'rażąca niewdzięczność' (Kilian 1996, 281)

'rażąca niewdzięczność (art. 898 § 1 k.c.)' (Banaszak 2005, 312)

Semantyczna rozpiętość leksemu sięga przy tym od znaczenia oczywisty / niewatpliwy, bezsporny, po znaczacy / wyraźny. Kontekstowo należy w tym wypadku interpretować leksem grob jako zwrot szacunkowy odnoszący się do wagi ocenianego stanu rzeczy. Analizując proponowane ekwiwalenty słownikowe warto zauważyć, że na analogię zastosowania terminów grober Undank i rażąca niewdzięczność wskazują nawet niektórzy autorzy leksykonów dwujęzycznych, podając obok ekwiwalentu leksykalnego odesłanie do stosownego artykułu k.c.

\section{Przykład 10.}

Art. 14. [...] § 2. Jednakże gdy osoba niezdolna do czynności prawnych zawarła umowę należącą do umów powszechnie zawieranych w drobnych bieżących sprawach życia codziennego, umowa taka staje się ważna z chwilą jej wykonania, chyba że pociąga za sobą rażące pokrzywdzenie osoby niezdolnej do czynności prawnych. (k.c. 2000, 6)

'Art. 14 [Rechtsgeschäft eines Geschäftsunfähigen]. [...] § 2. Ein von einem Geschäftsunfähigen in kleinen laufenden Angelegenheiten des täglichen Lebens geschlossener Vertrag wird jedoch mit seiner Erfüllung wirksam, es sei denn, dass er dem Geschäftsunfähigen erhebliche Nachteile bringt.' (poln. ZGB 2005, 5)

Z kolei termin rażace pokrzywdzenie, którego komponentem szacunkowym jest ten sam co wyżej przymiotnik rażacy, nie zostaje oddany w języku niemieckim poprzez leksem grob, lecz przy użyciu leksemu erheblich. Nakreślając kontekst użycia polskiego terminu należy wskazać, że art. 14 § 2 k.c. reguluje kwestię ważności umów zawieranych przez osobę niezdolną do czynności prawnych. Niemieckie prawo cywilne także posługuje się pojęciem nieostrym pokrzywdzenia (niem. Benachteiligung), np. 


\section{Comparative Legilinguistics 17/2014}

w kontekście pokrzywdzenia strony zobowiązania umownego wskutek nieprzestrzegania zwyczajów obrotu prawnego. Rażące pokrzywdzenie (unangemessene Benachteilugung) domniemywa się np. w sytuacji, w której postanowienie umowne w takim stopniu ogranicza wykonanie zasadniczych praw czy zobowiązań wynikających z natury umowy, że zagrożone jest osiągnięcie celu umowy.

Zachodzi tu jednak jedynie częściowa ekwiwalencja pojęciowa, gdyż wspomniany zwrot niemiecki wiązany jest kontekstem pokrzywdzenia strony w związku z postanowieniami zawartymi w ogólnych warunkach umowy (niem. AGB), więc wiązać się może też $\mathrm{z}$ taką sytuacją, że dochodzi do niego wskutek niejasności w sformułowaniu postanowienia. Kontekst użycia polskiego zwrotu ogranicza się w tym wypadku jedynie do umów powszechnie zawieranych w drobnych bieżących sprawach życia codziennego.

Zastąpienie przymiotnika grob przymiotnikiem erheblich może wynikać z analogii kontekstu użycia zwrotu erhebliche Gefahr für die Person oder das Vermögen des Geschäftsunfähigen w przepisie dotyczącym skuteczności umów bagatelnych zawieranych przez pełnoletnią osobę nieposiadającą zdolności do czynności prawnych.

\section{Przykład 11.}

$\S 105 \mathrm{a}$ Geschäfte des täglichen Lebens (1) ${ }^{1}$ Tätigt ein volljähriger Geschäftsunfähiger ein Geschäft des täglichen Lebens, das mit geringwertigen Mitteln bewirkt werden kann, so gilt der von ihm geschlossene Vertrag in Ansehung von Leistung und, soweit vereinbart, Gegenleistung als wirksam, sobald Leistung und Gegenleistung bewirkt sind. ${ }^{2}$ Satz 1 gilt nicht bei einer erheblichen Gefahr für die Person oder das Vermögen des Geschäftsunfähigen. (BGB 2002, 76)

[§105a Czynności prawne w drobnych sprawach życia codziennego (1) ${ }^{1} J e s ́ l i$ osoba pełnoletnia nie posiadająca zdolności do czynności prawnych dokonuje czynności prawnych $\mathrm{w}$ sprawach życia codziennego, których przedmiot nie stanowi wysokiej wartości, zawartą przez nią umowę uznaje się za skuteczną w momencie wykonania przez nią zobowiązania i, o ile ustalono umownie, wykonania zobowiązania przez stronę przeciwną. ${ }^{2}$ Punkt 1nie dotyczy czynności, które stanowiłyby rażące narażenie osoby nie posiadającej zdolności do czynności prawnych i jej majątku. $]^{4}$

Porównując zawartość obu przepisów, polskiego i niemieckiego, stwierdzić można, że zastosowany ekwiwalent tłumaczeniowy terminu erhebliche Nachteile jest adekwatny semantycznie i nie zatraca istoty nieostrości pojęcia pokrzywdzenia.

Przykład 12.

$\S 1565$ Scheitern der Ehe. [...] (2) Leben die Ehegatten noch nicht ein Jahr getrennt, so kann die Ehe nur geschieden werden, wenn die Fortsetzung der Ehe für den Antragsteller aus Gründen, die in der Person des anderen Ehegatten liegen, eine unzumutbare Härte darstellen würde. (BGB 2002, 370)

[§ 1565 Trwały rozkład pożycia małżeńskiego. [...] (2) Jeśli małżonkowie pozostają w separacji przez okres krótszy niż jeden rok, małżeństwo stron może

\footnotetext{
${ }^{4}$ Tłumaczenie pochodzi od autora artykułu, gdyż omawiany $§ 105 a$ nie znajdował się w BGB w brzmieniu kodeksu, jaki stanowił tekst wyjściowy do tłumaczenia.
} 
Karolina Kęsicka, Między precyzją a nieostrościa - o problematyce przekładu...

zostać rozwiązane przez rozwód tylko wtedy, gdy kontynuowanie związku małżeńskiego oznaczałoby dla strony pozywającej dolegliwość, powstałą z przyczyn leżących w osobie współmałżonka, której znoszenia nie można oczekiwać. $]^{5}$

Problematyczny przypadek dla thumacza stanowi także termin unzumutbare Härte, znajdujący zastosowanie m.in. w $\S 1565$ ust. 2 BGB. Jest on w nim wymieniony jako okoliczność stanowiącą podstawę do wydania orzeczenia rozwodu przed upływem wymaganego ustawowo okresu jednorocznej separacji małżonków. Małżonek powołujący się na zaistnienie tzw. Härtefall, musi w sposób niezbity przedstawić dowody na jego zaistnienie. Termin odwołuje się do subiektywnego odczucia strony, lecz podlega ocenie sądu, który według uznania orzeka, czy wskazane przez stronę okoliczności faktycznie stanowią $\mathrm{z}$ punktu widzenia prawa zbyt duże dla niej obciążenie, niesprawiedliwość czy rażącą krzywdę.

Problematyczność tłumaczenia tego terminu tkwi w braku ekwiwalencji semantycznej w polskim języku prawa. Polskie prawo rodzinne przewiduje jako jedną $\mathrm{z}$ przesłanek do nieudzielenia rozwodu sytuację, w której rozwód byłby sprzeczny $\mathrm{z}$ zasadami współżycia społecznego. Klauzula ta jednak w żadnej mierze nie może stanowić ekwiwalentu dla niemieckiego terminu, gdyż nie uwzględnia ona aspektu subiektywności oceny strony, lecz odsyła do powszechnie aprobowanych wartości. Ów brak ekwiwalencji przekłada się na propozycje ekwiwalentów w języku polskim:

\section{Przykład 13.}

niesprawiedliwość, której znoszenia przez dany podmiot nie można oczekiwać (Banaszak 2005, 324)

trudność, której znoszenia nie należy wymagać (Banaszak 2005, 607)

rażąca dolegliwość, której znoszenie nie może być wymagane (Kilian 2009, 347)

za daleko idąca rażąca dolegliwość (Kilian 2009, 687)

Wszystkie z nich mają charakter parafrazy i w sposób opisowy wskazują na kontekst użycia. Zaletą wymienionych propozycji jest fakt, że akcentują relewantny dla zwrotów szacunkowych element oceny intensywności zjawiska, np. poprzez przydawki „rażący”, „za daleko idący” czy też oddany konstrukcją czasownikową (,,.., której znoszenia nie można / należy wymagać").

Kwalifikowaniu przez ocenę podlega także pojęcie niedookreślone ehrloser Lebenswandel, którego wykładnia odsyła do powszechnie bądź prawnie zdefiniowanych zasad i postaw moralnych.

\section{Przykład 14.}

$\S 2333$ Entziehung des Pflichtteils eines Abkömmlings. Der Erblasser kann einem

Abkömmling den Pflichtteil entziehen:

[...] 5. wenn der Abkömmling einen ehrlosen oder unsittlichen Lebenswandel wider den Willen des Erblassers führt. (BGB 2002, 517)

'§ 2333. Spadkodawca może odjąć potomkowi zachowek:

[... 5) jeżeli potomek prowadzi bezecny lub niemoralny tryb życia wbrew woli spadkodawcy.' (KC, 1923)

\footnotetext{
${ }^{5}$ Jak wyżej.
} 
Analizowane pojęcie występuje w kontekście pozbawienia spadkobiercy prawa do zachowka. Przydawka ehrlos (pl. niegodny / nikczemny / bez honoru / niehonorowy / niesławny itp.) eksplikuje w niemieckim aspekt wartościujący, lecz jednocześnie jego semantyka pozostaje nieostra po to, by pozostawić pole do swobody interpretacji i luzu decyzyjnego. Takie rozumienie pojęcia jest bliskie rozumieniu postępowania niegodnego jako uporczywego postępowania $\mathrm{W}$ sposób sprzeczny $\mathrm{z}$ zasadami współżycia społecznego w myśl polskiego kodeksu cywilnego. Porównując brzmienie art. 1008 k.c., stanowiącego o okolicznościach dopuszczających pozbawienie spadkobierców zachowku, z cytowanym wyżej § 2333 BGB, stwierdzić można daleko idącą analogię:

\section{Przykład 15.}

Art. 1008. Spadkodawca może w testamencie pozbawić zstępnych, małżonka i rodziców zachowku (wydziedziczenie), jeżeli uprawniony do zachowku:

1) wbrew woli spadkodawcy postępuje uporczywie w sposób sprzeczny z zasadami współżycia społecznego;

2) dopuścił się względem spadkodawcy albo jednej z najbliższych mu osób umyślnego przestępstwa przeciwko życiu, zdrowiu lub wolności albo rażącej obrazy czci [...]. (k.c. 2000, 189)

W obu przepisach wskazuje się na element subiektywnej oceny zachowania spadkobiercy przez testatora, a w razie zakwestionowania woli spadkodawcy, przez stosującego prawo, celowo przy tym unikając dookreślenia granic akceptowalności / nieakceptowalności danego zachowania poprzez wprowadzenie do treści przepisów zwrotów szacunkowych oraz w polskim przepisie dodatkowo odesłania do klauzuli generalnej zasad współżycia społecznego.

Użyty w polskim przekładzie BGB przymiotnik bezecny nosi znamiona określenia nacechowanego stylistycznie językiem literackim i pozostaje dziś określeniem $\mathrm{w}$ tym kontekście $\mathrm{z}$ rzadka używanym, tym bardziej $\mathrm{w}$ języku prawnym unikającym form archaizujących. Dla porównania w leksykonach terminologicznych zdecydowanie dominuje tłumaczenie przy użyciu zwrotu ,niegodny tryb życia” (przykł. Kilian 2009, 438). Wydaje się ono adekwatne semantycznie, gdyż słusznie rodzi konotację z stylem życia naruszającym zasady obyczajowości.

\section{Przykład 16.}

Art. $355^{2} \S 1$. Dłużnik obowiązany jest do staranności ogólnie wymaganej w stosunkach danego rodzaju (należyta staranność).

$\S$ 2. Należytą staranność dłużnika w zakresie prowadzonej przez niego działalności gospodarczej określa się przy uwzględnieniu zawodowego charakteru tej działalności. (k.c. 2000, 63)

'Art. $355^{2}$ [Erforderliche Sorgfalt]. § 1. Der Schuldner hat die in Verhältnissen der gegebenen Art allgemein erforderliche Sorgfalt $\mathrm{zu}$ beachten (erforderliche Sorgfalt).

$\S 2$. Die erforderliche Sorgfalt des Schuldners im Bereich der von ihm ausgeübten wirtschaftlichen Tätigkeit bestimmt sich unter Berücksichtigung des beruflichen Charakters dieser Tätigkeit.' (poln. ZGB 2005, 65) 
Karolina Kęsicka, Między precyzją a nieostrościa - o problematyce przekładu...

Ostatni z omawianych przykładów odsyła we wskazanym przepisie do obowiązku zachowania przez dłużnika należytej staranności. Pod pojęciem tym polskie prawo cywilne rozumie pewien model postępowania, które uznawane jest za właściwe w ramach określonych czynności. Niedookreślony charakter pojęcia wynika $\mathrm{z}$ faktu przyjmowania $\mathrm{w}$ odniesieniu do dłużnika bardzo różnych wymagań co do jego postępowania. W wykładni art. $355 \S 1$ Sąd Najwyższy stwierdza m.in., że „wzorzec należytej staranności ma charakter obiektywny. Jego zastosowanie w praktyce polega najpierw na dokonaniu wyboru modelu, ustalającego optymalny w danych warunkach sposób postępowania, odpowiednio skonkretyzowanego i aprobowanego społecznie, a następnie na porównaniu zachowania się dłużnika z takim wzorcem postępowania" (Wyrok SN z dnia 23 października 2003 r. sygn. akt V CK 311/ 02, cyt. za Borowiecka 2011, 47). Jak zaznacza Borowiecka, o obiektywnym charakterze wzorca postępowania przesądza sformułowanie „staranność ogólnie wymagana”, wskazując, że „nieistotne są indywidualne cechy podmiotu, od którego wymaga się dochowania należytej staranności, natomiast liczy się powszechnie uważane za prawidłowe" (Borowiecka 2011, 47).

W analogiczny sposób kwestię obowiązku zachowania należytej staranności przez dłużnika reguluje BGB w $\S 276$ ust. 2 określając, że niedbalstwa dopuszcza się ten, kto nie dochowuje wymaganej w określonych kręgach staranności, posługując się w tym kontekście terminem die im Verkehr erforderliche Sorgfalt. Wykładnia przepisu i w tym przypadku wskazuje na obiektywny charakter wzorca postępowania, definiując należytą staranność jako taką, jakiej zwyczajowo oczekuje się w danej sytuacji w stosunkach danego rodzaju (np. w stosunkach obowiązujących w określonych kręgach zawodowych jak lekarze czy kupcy).

Analizując wybór ekwiwalentu tłumaczeniowego stwierdzić można, że relacja całkowitej ekwiwalencji semantycznej pojęcia należyta staranność i erforderliche Sorgfalt na gruncie prawa zobowiązań znajduje pełne odzwierciedlenie w decyzji tłumacza. Z całą pewnością słusznie decyduje się na użycie lexemu erforderlich na oddanie terminu należyty, a rezygnuje z zastosowania leksemu geboten (pol. należyty), stanowiącego w języku ogólnym synonim, lecz w języku prawnym używanym w kontekście odpowiedzialności cywilnej pracodawcy w prawie zobowiązań w szwajcarskim porządku prawnym. Zastosowanie leksemu geboten mogłoby zatem skutkować niesłusznym zasugerowaniem w tym względzie analogii pojęciowej między polskim a szwajcarskim prawem zobowiązań. W uzupełnieniu do omawianego pojęcia Sorgfalt warto wskazać jako problematyczny dla thumacza także termin Sorgfalt eines ordentlichen Kaufmanns, występujący w niemieckim prawie handlowym. Trudność w thumaczeniu tego terminu rodzi się już w odniesieniu do leksemu kupiec, którego rozumienie $\mathrm{w}$ niemieckim języku prawnym jest odmienne aniżeli w polskim i stąd stanowi przykład terminu bezekwiwalentnego. W kontekście tematu poruszanego w niniejszym artykule istotniejszym będzie jednak przymiotnik ordentlich, którego warianty leksykalne $\mathrm{w}$ języku polskim to m.in. porządny / regularny / zwyczajny / należyty / staranny. W niemieckim HGB definiuje on należyty w myśl przepisów sposób zachowania kupca, nakładając na niego obowiązek przestrzegania w obrocie prawnym, a więc w kontaktach związanych $\mathrm{z}$ prowadzeniem działalności, miejscowo przyjętych obyczajów oraz postępowania tak, jak przystoi sumiennemu kupcowi. 


\section{Comparative Legilinguistics 17/2014}

Proponowane w słownikach specjalistycznych ekwiwalenty terminologiczne dla terminu ordentlicher Kaufmann to:

\section{Przykład 17.}

kupiec rzetelny (Kilian 2009, 520)

kupiec $w$ rozumieniu art. 2 pol. k.h. (Skibicki 1990,316)

Wybór ekwiwalentu leksykalnego „rzetelny” akcentuje aspekt uczciwego zachowania w obrocie handlowym (ważny w kontekście zasad uczciwej konkurencji) i w tym względzie jest adekwatnym ekwiwalentem. Zdecydowanie inną strategię obrano w drugim wariancie tłumaczenia, w którym wskazuje się na analogię pojęciową, rezygnując jako tako $\mathrm{z}$ tłumaczenia elementu wartościującego. Odesłanie do podobieństwa $\mathrm{W}$ definiowaniu pojęcia kupiec przez niemieckie i polskie prawo handlowe jest o tyle uzasadnione, że polski kodeks handlowy w istocie przejął z niemieckiego definicję kupca. Analogia straciła jednak podstawę z chwilą zniesienia kodeksu handlowego 1 stycznia 2001. Tym samym proponowany ekwiwalent uznać należy za nieadekwatny, gdyż nie eksplikuje tak istotnego dla tego terminu odesłania do przyjętej normy zachowania.

\section{Podsumowanie}

Pojęcia nieokreślone, do których zaliczyć należy omawiane w artykule klauzule generalne oraz zwroty szacunkowe, występują w obu porównywanych porządkach prawnych, pełniąc w nich funkcję instrumentu uelastyczniania prawa. Analiza prawnoporównawcza pozwoliła na stwierdzenie, że zwłaszcza w odniesieniu do klauzul generalnych porównywane pojęcia wykazują przeważająco pełną ekwiwalencję semantyczną. Pozwala to zatem thumaczowi / terminologowi na sięganie po ekwiwalenty funkcjonalne w języku docelowym i odejście od tłumaczenia dosłownego. Na przykładzie niemieckiego tłumaczenia polskiego kodeksu cywilnego widać jednak, że thumacz nie stosował $\mathrm{w}$ nim konsekwentnie strategii substytucji terminologicznej. Dla przykładu, w tłumaczeniu klauzuli zasad współżycia społecznego sugeruje wprawdzie analogię między polskim terminem i niemieckim terminem Treu und Glauben umieszczając termin ostatni w śródtytule artykułu, lecz w samej treści artykułu rezygnuje z proponowanego ekwiwalentu na rzecz tłumaczenia dosłownego. Podobnie $\mathrm{w}$ odniesieniu do terminu ustalone zwyczaje stosuje parafrazę $\mathrm{w}$ miejsce substytucji (Verkehrssitte). Jedynie w kontekście klauzuli billiges Ermessen analogia w zakresie rozumienia tejże klauzuli i polskiej klauzuli zasad słuszności znajduje odzwierciedlenie w doborze ekwiwalentów słownikowych.

Z kolei analiza prawno-porównawcza w zakresie najczęściej stosowanych niemieckich i polskich zwrotów szacunkowych pokazuje, że w odniesieniu do zwrotów szacunkowych częściej mamy do czynienia $\mathrm{z}$ jedynie częściową ekwiwalencją pojęciową lub nawet jej brakiem. Przekłada się to siłą rzeczy na pracę thumacza / terminologa, nakładając na niego obowiązek ustalenia, w jakim zakresie zachodzi zbieżność pojęciowa i terminologiczna. Oceniając pod kątem adekwatności propozycje ekwiwalentów słownikowych i tłumaczeniowych omawianych zwrotów szacunkowych zauważyć można, że dobór ekwiwalentów w tym wypadku konsekwentnie odzwierciadla wyniki analizy prawno-porównawczej. Potwierdza to choćby analiza 
Karolina Kęsicka, Między precyzją a nieostrościa - o problematyce przekładu... ekwiwalentów thumaczeniowych zwrotów szacunkowych rażaca niewdzięczność i rażace pokrzywdzenie, które mimo wspólnej podbudowy leksykalnej w postaci przymiotnika rażacy jako komponentu szacunkowego, nie zostają oddane w procesie tłumaczenia $\mathrm{w}$ drodze dosłowności, lecz odwołują się każdorazowo do analogii pojęciowej. Tłumacz świadomie rezygnuje z dosłowności, a w przypadku thumaczenia zwrotu rażace pokrzywdzenie także $\mathrm{z}$ zastosowania synonimii leksykalnej, która skutkowałaby przesunięciem kontekstowym thumaczenia. Potwierdzeniem konsekwencji wyborów tłumacza, opartych na komparatystycznej analizie polskiego i niemieckiego porządku prawnego, jest także sięgnięcie w thumaczeniu zwrotu szacunkowego należyta staranność po leksem erforderlich, który odsyła do niemieckiego zwrotu die im Verkehr erforderliche Sorgfalt, a nie po leksem geboten, którego uzus terminologiczny rodziłby raczej konotacje z szwajcarskim porządkiem prawnym. W odniesieniu do zwrotu szacunkowego unzumutbare Härte stwierdzony w toku analizy prawno-porównawczej brak ekwiwalencji pojęciowej zmusza do poszukiwania potencjalnych akceptowalnych ekwiwalentów. Nie dziwi zatem, że proponowane ekwiwalenty słownikowe przyjmują formę parafrazy, za pomocą której eksplikowane jest znaczenie oryginalnego terminu.

Dokonując wreszcie porównania ekwiwalentów tłumaczeniowych i słownikowych analizowanych terminów, konfrontowanych tam, gdzie zachodziły rozbieżności w sformułowaniu, stwierdzić można, że większą precyzję terminologiczną wykazują ekwiwalenty zastosowane w dwujęzycznych słownikach języka prawnego. Przeważająco mają one charakter substytucji, często przy tym towarzyszy im w uzupełnieniu odesłanie do stosownego przepisu we właściwej dziedzinie docelowego porządku prawnego. Należy w tym miejscu jednak zaznaczyć, że analizowane ekwiwalenty thumaczeniowe pochodziły z historycznego już dziś tłumaczenia BGB z lat dwudziestych XX w. Ów dystans czasowy thumaczy zapewne zdecydowane ciążenie tłumaczenia ku dużej dosłowności, budowanej w oparciu o język ogólny, często nacechowany stylistycznie literacką odmianą języka. Poza tym uwzględnienia w ocenie adekwatności przekładu wymaga też fakt, że $\mathrm{w}$ momencie powstawania thumaczenia BGB niektóre $\mathrm{z}$ omawianych $\mathrm{w}$ artykule pojęć nieokreślonych nie mogły pozostawać $w$ relacji ekwiwalencji względem siebie.

$\mathrm{Z}$ wyników badania wybranych terminów nazywających pojęcia nieokreślone nasuwa się refleksja, że głównymi źródłami problematyczności ich tłumaczenia są:

(i) specyfika pojęć niedookreślonych: brak definicji, zróżnicowany stopień ich precyzji, zamierzona przez prawodawcę semantyczna nieostrość i otwartość pojęć, by zapewnić prawu elastyczność;

(ii) konieczność wykładni pojęć $\mathrm{z}$ powodu braku definicji, dodatkowo utrudnione przez możliwość odmiennej interpretacji pojęcia w różnych porządkach prawnych;

(iii) wysokie ukontekstowienie rozumienia terminu (w przepisie / normie prawnej);

(iv) właściwy dla terminologii fachowej różny stopień ekwiwalencji semantycznej (szczególnie problematyczne to terminy bezekwiwalentowe);

(v) kwestia osiągnięcia precyzji thumaczenia (być może mamy tu do czynienia z przypadkiem nieprzetłumaczalności a priori?);

(vi) specyfika kulturowa: odesłania do norm pozaprawnych (moralnych, obyczajowych, systemów wartości). 


\section{Comparative Legilinguistics 17/2014}

Niniejsza analiza potwierdziła, jak ważnym instrumentem w procesie tłumaczenia języka prawnego jest komparatystyka prawnicza. Zwłaszcza w przypadku terminów niedookreślonych jest wręcz ona nieodzowna, bowiem pozwala poprzez kontekstową analizę uzusu terminologicznego na określanie stopnia analogii pojęciowej i ekwiwalencji funkcjonalnej terminu. Tam, gdzie nieprecyzyjny pozostaje język, konieczna staje się dogłębna interpretacja pojęcia, by zachować w tłumaczeniu terminu właściwy dla danego pojęcia poziom nieokreśloności. Wykorzystany w badaniu model analizy potwierdza zatem pierwszeństwo analizy prawno-porównawczej przed analizą językową, a wyniki analizy wskazują na konieczność dalszego pogłębiania dyskursu interdyscyplinarnego między teorią przekładu a komparatystyką prawniczą w celu wypracowania bardziej kompleksowego modelu analizy.

\section{Bibliografia}

Bocquet, Claude, 1994. Pour une méthode de traduction juridique. Prilly: CB Service SA.

Borowiecka, Urszula, 2011. Rażące niedbalstwo i niedochowanie należytej staranności na tle orzecznictwa Sądu Najwyższego, sądów powszechnych i skarg wpływających do Rzecznika Ubezpieczonych. Monitor Ubezpieczeniowy, Zeszyt 45, 47-51.

Constantinesco, Léontin-Jean, 1972. Rechtsvergleichung. Bd II. Die rechtsvergleichende Methode. Köln, Berlin, Bonn, München: Carl Heymann Verlag.

Engisch, Karl, 2010. Einführung in das juristische Denken. Stuttgart, Berlin, Köln: Kohlhammer.

Gajda, Stanisław, 1976. Specyfika terminologii naukowo-technicznej z językoznawczego punktu widzenia. W Problemy badawcze terminologii naukowo-technicznej, red. Tadeusz Frankiewicz, 15-27, Wrocław: Wydawnictwo Politechniki Wrocławskiej.

Heidenhain, Stephan, 2000. Das Verbraucherschutzrecht in Polen und der Europäischen Union. Eine Untersuchung anhand der Problematik der Allgemeinen Geschäftsbedingungen $(A G B)$. Berlin, Heidelberg, New York: Springer.

Kötz, Hein / Zweigert, Konrad, 1996. Einführung in die Rechtsvergleichung auf dem Gebiete des Privatrechts. Tübingen: C.B.Mohr Verlag.

Müller-Tochtermann, Helmut, 1959. Struktur der deutschen Rechtssprache. Beobachtungen und Gedanken zum Thema Fachsprache und Gemeinsprache. Muttersprache 59, 84-92.

Pajor, Tomasz, 2009. Kilka uwag o roli ocen etycznych w prawie cywilnym. Annales. Etyka w życiu gospodarczym, Zeszyt 12, nr 2, 135-140.

Pinkal, Manfred, 1980. Semantische Vagheit: Phänomene und Theorien. Teil I. Linguistische Berichte 70, 1-26.

Pinkal, Manfred, 1985. Logik und Lexikon. Die Semantik des Unbestimmten. Berlin, New York: de Gruyter. 
Karolina Kęsicka, Między precyzją a nieostrościa - o problematyce przekładu...

Piszko, Robert, 2001. Klauzule generalne, odesłania, luzy decyzyjne. Ruch prawniczy, ekonomiczny i socjologiczny, Zeszyt 1-2, 221-232.

Šarčević, Susan, 1997. New Approach to Legal Translation. The Hague: Kluwer Law International.

Zieliński, Maciej, 2012. Wykładnia prawa. Zasady, reguły, wskazówki. Warszawa: LexisNexis.

Zieliński, Tadeusz, 1988. Klauzule generalne w prawie pracy. Warszawa: PWN.

\section{Źródła}

Banaszak, Bogusław, 2005. Rechts- und Wirtschaftswörterbuch. Deutsch-Polnisch. Warszawa: C.H. Beck.

Bürgerliches Gesetzbuch, 2002. 52. Auflage. München: Deutscher Taschenbuch Verlag. Handelsgesetzbuch. http://www.gesetze-im-internet.de/hgb (data dostępu 04.09.213).

Kodeks cywilny, 2000. 11. wydanie. Warszawa: C.H. Beck.

Kodeks Cywilny obowiąujący na Ziemiach Zachodnich Rzeczypospolitej Polskiej (przekład urzędowy), T. X, 1923. Warszawa Poznań: Wydawnictwo Departamentu Sprawiedliwości Ministerstwa byłej dzielnicy pruskiej. http://www.pwsz.legnica.edu.pl/ siejam/ustawy/bgb.doc (data dostępu 04.09.213).

Kilian, Alina, 1996. Słownik języka prawniczego i ekonomicznego. Niemiecko-Polski. Warszawa: C.H. Beck.

Kilian, Alina, 2009. Słownik języka prawniczego i ekonomicznego. Niemiecko-Polski. Warszawa: C.H. Beck.

Kozieja-Dachterska, Agnieszka, 2006. Großwörterbuch der Wirtschafts- und Rechtssprache. Deutsch-Polnisch Band I. Warszawa: C.H. Beck.

Skibicki, Wacław, 1990. Słownik terminologii prawniczej i ekonomicznej: niemieckopolski. Warszawa: Wiedza Powszechna.

Zivilgesetzbuch, 2005. W Polnische Wirtschaftsgesetze, übersetzt von Dr. Alexander Lane, 1-227, Warszawa: C.H. Beck. 